\title{
Made in Sachsenhausen. Rekontekstualizacja i reapropriacja odwróconego różowego trójkąta wśród grup gejowsko- lesbijskich w Ameryce Północnej jako przykład kradzieży symbolicznej
}

\author{
Kornelia Kajda i Tomasz Michalik
}

Uniwersytet Adama Mickiewicza

\begin{abstract}
[Artkuł ukazał się wcześniej na łamach InterAliów w sekcji artykuły bieżące, tutaj.]
Procesy rekontekstualizacji oraz reapropriacji w kontekście dyskursów dotyczacych mniejszości seksualnych uznawane sa za podstawowe zabiegi umożliwiające znoszenie narzucanych na ta grupę stygmatów. W odniesieniu do wspomnianych procesów, niniejsza praca podejmuje problematykę zmiany konotacji oraz znaczenia silnie uwarunkowanego historycznie symbolu różowego trójkąta. Autorzy poprzez prześledzenie różnych kontekstów, w których wspótcześnie występuje wspomniany symbol - komemoracyjnych, emancypacyjnych oraz związanych z kultura pop - podejmuja refleksję nad konsekwencjami związanymi z dażeniami do odłaczenia różowego trójkąta od symboliki holocaustowej. Poprzez zastosowanie metafory kradzieży dodatkowo podjęta zostaje próba zwrócenia uwagi na fakt, że ograniczenia dotyczące prawa własności dotycza nie tylko przedmiotów materialnych, ale również wartości symbolicznych. Praca w oparciu o koncepcję performatywności aktów mowy J. Butler, reapriopriacji w ujęciu A. Crooma oraz Goffmanowskie rozumienie piętna zawiera analizę sposobów wykorzystywania symbolu różowego trójkąta w ramach wspótczesnych dyskursów tworzonych w USA. Gtówne pytanie stawiane przez autorów dotyczy kwestii wtasności. Do kogo zatem wspótcześnie należy różowy trójkąt - do byłych więźniów, dla których jest on piętnem, do środowisk LGBT nosząych go z duma, czy może do użytkowników wspótczesnej kultury, używających go jako dodatek do różnego rodzaju gadżetów?
\end{abstract}

Słowa kluczowe: różowy trójkąt, symbolika, holocaust, piętno, popkultura

\section{Wprowadzenie - holocaustowy szaberek}

Po raz pierwszy na motyw kradzieży symbolicznej natrafiliśmy, poznając historię pomnika Prometeusza postawionego w Prypeci nieopodal Czarnobyla. Opowieść o szlachetnym zrabowaniu ognia została wykorzystana w czasach powstawania elektrowni jako symbol spełnienia mitologicznego dziedzictwa i tryumfu człowieka nad energią. Po tragicznym kwietniu 1986 roku ten sam pomnik przeniesiony z miasteczka w pobliże elektrowni - przestał oznaczać chwałę i szlachetność Prometeusza, nawiązując raczej do tragicznych skutków postępowania jago brata Epimeteusza, który według mitologii otworzył puszkę Pandory. O ile więc Prometeusz zdołał oszukać bogów, wykradając im ogień, o tyle - w przypadku Czarnobyla - równocześnie sam został oszukany przez ludzi, którzy skradli jego tryumf i przekuli w hańbę poprzez umieszczenie monumentu w kontekście zniszczonego reaktora (Czarnobyl). Niezmieniona forma pomnika posłużyła raz za powód dumy, innym zaś razem za znak klęski. W niniejszym tekście chcielibyśmy podjąć refleksję nad złożoną relacją pomiędzy kradzieżą symboliczną, zjawiskiem reapropriacji oraz procesem rekontekstualizacji, 
rozpatrując je w odniesieniu do dyskursów tworzonych przez mniejszości seksualne - gejowskie i lesbijskie - wokół Holocaustu ${ }^{1}$.

Samo zagadnienie rabunków w kontekście miejsc pamięci o Shoah stanowi problem, który - jak się wydaje - za sprawą kradzieży w 2009 roku napisu znad bramy wejściowej do byłego obozu Auschwitz i wszedł w Polsce do ogólnospołecznej debaty oraz świadomości. O ile sprawców tego czynu jednoznacznie potępiono (Sidorowicz 2010), o tyle nieco więcej dylematów pojawia się w nawiązaniu do doniesień prasowych o próbie wywiezienia w charakterze relikwii drutu z Auschwitz przez Włocha, którego ojciec zginął we wspomnianym obozie (Próbowat wywieźć drut kolczasty z Auschwitz 2012), czy nieudanego przemytu fragmentów łyżek, ostrzy noży czy nożyczek zebranych z ziemi na terenie Auschwitz II Birkenau przez małżeństwo z Izraela (Zapadt wyrok w sprawie kradzieży 2012). W ramach tej pracy zamierzamy zastanowić się nad jeszcze innym zjawiskiem, a mianowicie, co dzieje się, kiedy z terenu byłego obozu koncentracyjnego wynoszone są nie tyle materialne przedmioty, ale symbole? Czy jest to rodzaj niewinnego holocaustowego szaberku²? Niniejszy artykuł prezentuje analizę sposobów wykorzystywania symbolu odwróconego różowego trójkąta przez społeczności homoseksualne w USA. Autorzy podejmują w nim refleksję nad konotacją oraz denotacją wspomnianego symbolu. Tekst poprzez zestawienie historycznych, jak i współczesnych sposobów wykorzystywania reprezentacji odwróconego różowego trójkąta, jest próbą uchwycenia zjawiska kradzieży symbolicznej poprzez refleksję nad rekontekstualizacją oraz reapropriacją jednego z symboli holocaustowych.

W pierwszej kolejności zostaną przedstawione informacje związane ze znaczeniem różowego trójkąta w odniesieniu do obozów koncentracyjnych oraz ideologii nazistowskiej. Następnie zaprezentowana zostanie problematyka jego współczesnego wykorzystywania. Część trzecia - w nawiązaniu do przeszłego, jak i obecnego sposobu używania różowego trójkąta - zawiera omówienie kontekstów, w jakich występuje wspomniany symbol. W dalszej kolejności przedstawiona zostanie koncepcja kradzieży symbolicznej. W końcowej części artykułu dokonano analizy roli praktyk emancypacyjnych, komemoratywnych, a także kultury pop w procesie zmiany konotacji oraz denotacji wspomnianego symbolu.

\section{Różowy paragraf}

Historia odwróconego trójkąta, który dziś jest jednym z symboli emancypacji środowisk gejowskich i walki o ich równouprawnienie rozpoczyna się podczas II wojny światowej w nazistowskich Niemczech. Paragraf 175 Kodeksu Karnego, na mocy którego skazywano homoseksualistów (mężczyzn), został wprowadzony w 1871 roku wraz z proklamowaniem Cesarstwa Niemieckiego i określał homoseksualizm mężczyzn na równi z zoofilią jako „nierząd przeciw naturze karany więzieniem”

1 W prezentowanej pracy używamy terminu Holocaust nie tylko w rozumieniu eksterminacji Żydów, ale w znaczeniu szerszym zaproponowanym przez Daniela Levvego i Natana Sznaidera w The Holocaust and Memory in the Global Age (2004), jako uniwersalnego symbolu zła wykorzystywanego przez różne grupy, nie tylko w kontekście II wojny światowej. Ze względu na to, że głównym przedmiotem refleksji niniejszej pracy są praktyki społeczne, stosujemy kategorie pojawiające się w analizowanych źródłach - w tym pojęcie Holocaustu w znaczeniu eksterminacji mniejszości seksualnych.

2 Posługując się metaforą kradzieży, chcemy nie tyle zwrócić uwagę na to, że jakiś czyn jest nielegalny i powinien zostać ukarany, co zauważyć podobieństwo samych czynności: kradzieży materialnej i symbolicznej w postaci "wynoszenia” i „przywłaszczania” sobie czegoś. 
(Connelly 2010: 281). Po przejęciu władzy przez NSDAP został on zaostrzony poprzez dodanie paragrafu 175a (1935 rok). Na jego podstawie skazywano za domniemane lub jawne akty homoseksualne wielu mężczyzn (również niehomoseksualistów) na karę więzienia, a podczas II wojny światowej na zesłanie w obozach koncentracyjnych (Weseli 2007). Wraz z systemem nazistowskim rozpoczyna się historia różowego trójkąta, ponieważ to właśnie tym symbolem oznaczani byli homoseksualiści (lub osoby, u których podejrzewano skłonności homoerotyczne) w obozach koncentracyjnych (Weseli 2007: 427-428³. Różowy kolor dobrany został przez nazistów w sposób celowy. Miał on wskazywać na zniewieściałość oznaczonych nim mężczyzn i ich kobiece cechy. Dodatkowo różowy trójkąt był większy od trójkątów innego koloru. Najprawdopodobniej jego większy rozmiar miał na celu szczególne uwidocznienie osób homoseksualnych znajdujących się w obozie (Elman 1996). Homoseksualiści nie stanowili dla nazistów celu bezpośredniej eksterminacji. Szacuje się, że w obozach koncentracyjnych mogło ich zginąć od 5 do 10 tysięcy (choć niektóre statystyki wskazują na liczbę 15 tysięcy) osób, w większości z powodu różnych chorób, wygłodzenia lub tortur (Conelly 2010: 282). Według oficjalnej polityki nazistów homoseksualiści byli wtrącani do obozów koncentracyjnych w celu ich reedukacji. Pobyt w obozie miał zmienić ich zachowania seksualne. Homoseksualizm uważano za chorobę, którą można wyleczyć. Sposobami jej leczenia miały być np. regularne wizyty w obozowych "domach publicznych", w trakcie których zmuszano kobiety i skazańców spod paragrafu 175 do odbywania stosunków seksualnych. Stosowano również kastrację oraz zastrzyki z testosteronu, które miały na celu doprowadzenie skazańców do stanu "normalności" seksualnej, a także ukaranie ich za "nienormalne” zachowania seksualne (Elman 1996). Z kolei w obozie koncentracyjnym Sachsenhausen homoseksualni mężczyźni trzymani byli w osobnych blokach. Musieli spać tylko w specjalnych koszulach nocnych z rękoma na kocu, aby strażnicy mogli dokładnie obserwować ich zachowanie i nie dopuścić do żadnego intymnego kontaktu między osobami dzielącymi pryczę. Dodatkowo w barakach homoseksualistów przez cały czas świeciło się światło, co także miało ułatwić kontrolę strażnikom, a więźniom znacznie utrudniało sen (Homocaust). Mimo tego, że homoseksualiści nie byli skazywani jednoznacznie na śmierć; podczas pobytu w obozie padali oni często ofiarą szczególnie złego traktowania. Ze względu na swe preferencje seksualne (oznaczone różowym trójkątem) znajdowali się bardzo nisko w hierarchii obozowej i rzadko mogli liczyć na pomoc współwięźniów. Naszyty na obozowym stroju symbol stygmatyzował ich nie tylko w oczach nazistów, ale także współwięźniów, którzy często nie akceptowali odmienności seksualnej. Różowy trójkąt stanowił piętno, które określało homoseksualistów także poza rzeczywistością obozową i wpływało na ich życie nawet po zakończeniu II wojny światowej. Zdarzało się, że homoseksualiści, którzy wyszli z obozu, żenili się i zakładali rodziny. Taki wybór miał zatuszować ich preferencje seksualne, które nadal były nieakceptowane przez społeczeństwo i państwo. Biorąc pod uwagę fakt, że w Niemczech paragraf 175 został zniesiony dopiero w 1994 roku, należy stwierdzić, że osoby homoseksualne nie tylko pozbawione były akceptacji, ale również przez długi czas po wojnie były zagrożone sankcjami prawnymi ${ }^{4}$ Zatem różowy trójkąt był sym-

3 Początkowo homoseksualni mężczyźni oznaczani byli literą "A", która naszywana była na lewej piersi lub na nogawce spodni. Litera "A" oznaczała „Arschficker”, co można przetłumaczyć jako „wkładający w tyłek”. Niektórych oznaczano także dużą czarną kropką na ramieniu pasiaka i cyframi 175 napisanymi z tyłu ubrania (Homocaust).

${ }^{4}$ Według informacji przekazywanych w filmie Paragraf 175 więźniowie skazani z tytułowego paragrafu nie mogli przyznawać się po wyjściu z obozu, za co zostali skazani. Co więcej, na uznanie ich za ofiary zbrodni nazistowskich musieli czekać jeszcze kilkadziesiąt lat po zakończeniu II wojny światowej, a pierwsze odszkodowania za straty poniesione podczas II Wojny Światowej zaczęły być im wypłacane w 2000 roku. 
bolem, który w znaczny sposób przeniósł swoje znaczenie w przestrzeń pozaobozową. Mimo jego braku na piersi, już po odbyciu kary w obozie, nadal stygmatyzował, odciskając swoje piętno w psychice skazanego. Zmuszał go bowiem do ukrywania prawdziwych powodów zesłania do obo$z u^{5}$. Homoseksualizm kobiet traktowany był w inny sposób niż homoseksualizm mężczyzn. Różnica w pojmowaniu i traktowaniu lesbijek i gejów wynikała z tego, że naziści nie uznawali takiego zjawiska jak homoseksualizm kobiecy. W związku z tym, że wypierano je tak silnie ze społecznej egzystencji, nie istniał paragraf, który pozwalałby na skazywanie lesbijek za czyny homoseksualne. Taki stan rzeczy wynikał ze specyficznego pojmowania roli kobiety i kobiecości w ideologii nazizmu. Naziści uważali, że kobiety służą przede wszystkim jako narzędzie do reprodukcji a ich główną rolą społeczną jest rodzenie zdrowych obywateli Niemiec, zatem najważniejsza była dla nich rola kobiety jako matki. Sądzono również, że kobiety podejmują decyzje mniej świadomie niż mężczyźni (między innymi te dotyczące preferencji seksualnych). Wiązało się to z przekonaniem, że łatwiej można na kobiety wpłynąć i je zmienić, zatem nie trzeba było podejmować wobec nich tak bezpośrednich kroków prawnych (Weseli 2007: 426). Mimo to wiele homoseksualnych kobiet trafiało do obozów koncentracyjnych. Uznawano je wówczas za osoby asocjalne i oznaczano odwróconym czarnym trójkątem. Istotnym faktem związanym z czarnym trójkątem jest to, że oznaczał on także osoby przebywające w obozie za morderstwa, kradzieże, prostytucję, włóczęgostwo oraz stosunki seksualne pomiędzy osobami rasy aryjskiej i Żydami. Zatem samo oznaczenie nie było tak jednoznaczne jak w przypadku mężczyzn, dlatego lesbijki były często "niewidoczne” w ramach struktur obozowych (Elman 1996).

\section{Różowy trójkąt - (u)życia poholocaustowe}

Wyzwolenie obozów koncentracyjnych oraz zakończenie II wojny światowej nie wiązało się z zaprzestaniem używania symboliki stworzonej przez nazistów. Przykładowo, powołany w 1946 roku Polski Związek Byłych Więźniów Politycznych Hitlerowskich Więzień i Obozów Koncentracyjnych jako swój symbol ustanowił czerwony trójkąt z literą "P" na tle obozowego pasiaka (Polski Związek Byłych Więźniów). O ile jednak - poprzez tę decyzję - symbol czerwonego trójkąta na trwałe został wpisany w dyskurs martyrologiczny, o tyle w przypadku różowego trójkąta możemy zauważyć swoisty dwugłos w sposobach jego wykorzystywania. Pierwszym z kontekstów, w jakim pojawia się wspomniany symbol, jest sfera pamięci. W Stanach Zjednoczonych upamiętnianie za pomocą różnego rodzaju pomników homoseksualistów, którzy zginęli w obozach koncentracyjnych, rozpoczyna się w latach 90. XX wieku6. Większość ze wspomnianych monumentów oparta jest na motywie różowego trójkąta. Przykładami tego rodzaju prac mogą być pomniki w Anchorage na Alasce (odsłonięty w 1999 roku) czy w San Francisco (1999) (The Gay Holocaust). Pierwszy z nich - znajdujący się na lokalnym cmentarzu - ma postać grafitowej płyty nagrobnej z napisem „Your Spirit Lives on, in Love, Peace and Pride" i z różowym trójkątem umieszczonym w jej lewym górnym rogu. Pomnik powstały w San Francisco jest natomiast projektem większym i składa się z 15 kamiennych steli przeciętych w taki sposób, że ich powierzchnia górna ma kształt trójkątów. W zamyśle autorów, każdy z grafitowych słupów ma symbolizować kolejne 1000 homoseksualnych ofiar obozów zagłady. Monumenty te - co warto zauważyć - stają się symbolem nie tylko dla społeczności ge-

${ }^{5}$ Na podstawie wywiadów z filmu Paragraf 175 w reżyserii Roba Epsteina i Jeffreya Friedmana z 2000 r.

6 W Europie proces ten rozpoczęto już w latach 80. Przykładami wspomnianych monumentów mogą być: pomnik w Mathausen (odsłonięty w 1984 roku), Dachau (odsłonięty w 1985) czy w Amsterdamie (odsłonięty w 1987). 
jowskich, ale są również wykorzystywane w dyskursach pamięci tworzonych przez grupy lesbijskie, biseksualne czy transgenderowe. Oprócz wspomnianych powyżej pomników, przykładem takiego typu projektu może być "Gay \& Lesbian Holocaust Memorial - Green Park" w Sydney, gdzie różowy trójkąt służy zarówno upamiętnieniu gejów, jak i lesbijek (Gay and Lesbian Holocaust Memorial). Charakterystyczny dla omawianego dyskursu pamięci jest fakt, że choć symbol ten pojawia się w kontekście różnego rodzaju monumentów, praktycznie nie powraca w przestrzeń Zagłady (Homoseksualiści oddali hołd ofiarom Holokaustu 2005) ${ }^{7}$ - tak jak ma to miejsce za sprawą byłych więźniów politycznych, którzy wracają z symbolem czerwonego trójkąta podczas różnego rodzaju uroczystości w miejscach pamięci w byłych obozach koncentracyjnych i obozach zagłady. W przeciwieństwie do tej sytuacji różowy trójkąt jest obecnie chętnie noszony w zupełnie innym znaczeniu emancypacyjnym - przez nie-więźniów. Drugi z kontekstów dotyczy ruchów gejowskich powstałych w latach 70. W Stanach Zjednoczonych. Środowiska te za jeden ze swoich symboli uznały odwrócony różowy trójkąt (Elman 1996). Symbol ten szybko stał się znakiem walki o wolność i godność dla mniejszości seksualnych. Obok tęczowej flagi został on uznany za jeden z głównych symboli międzynarodowego ruchu emancypacyjnego (LGBT na świecie i w Polsce). Przejęcie odwróconego różowego trójkąta w latach 70. I 80. XX wieku związane było z pojawiającymi się ówcześnie silnymi tendencjami zmierzającymi ku rewizji historii i ukazaniu jej również z perspektywy gejowsko-lesbijskiej. Homoseksualni działacze i działaczki starali się odnieść do wydarzeń z czasów II wojny światowej, by wskazać na pewne podobieństwa w traktowaniu mniejszości seksualnych jako ofiar oraz aby przypomnieć o ich prześladowaniach i ich tragicznych skutkach. Polityka "by nigdy nie zapomnieć" miała oznaczać, że homoseksualiści także posiadają swoją pamięć historyczną i uważają się za potomków swoich braci i sióstr zamordowanych w obozach koncentracyjnych (Stein 1998). Działania takie otworzyły równocześnie możliwość zupełnej rekontekstualizacji i przewartościowania nazistowskiego symbolu z przedmiotu hańby w znak dumy.

\section{Trójkąt w kontekstach}

Jak można zauważyć podczas czytania powyższych części artykułu, odwrócony różowy trójkąt pojawia się w kilku różnych kontekstach, zarówno czasowych, przestrzennych, jak i związanych z używającą go grupą. Na potrzeby tej pracy wyróżnić można pięć podstawowych kontekstów „życia” wspomnianego symbolu. Pierwszy z nich, kontekst obozowo-nazistowski, odnosi się do czasów związanych z II wojną światową i pierwotnego miejsca użytkowania odwróconego różowego trójkąta, tj. obozów koncentracyjnych. W tym przypadku symbol ten noszony był jedynie przez homoseksualnych mężczyzn (lub tych podejrzewanych/posądzonych o zachowania homoerotyczne) w ramach obozu koncentracyjnego, w którym odbywali karę za określone preferencje seksualne (lub podejrzenia o nie). Wtedy odwrócony różowy trójkąt narzucany był przez dominującą grupę (nazistów) mniejszości seksualnej i miał on na celu jej stygmatyzację. Zatem wówczas symbol ten odnosił się do konkretnej grupy osób (mężczyzn oskarżonych o homoseksualizm i skazanych na pobyt w obozie koncentracyjnym) i wjednoznacznie negatywny sposób miał on naznaczać tę mniejszość. Kolejne dwa konteksty, które można wyróżnić, ściśle łączą się ze sobą i związane są

\footnotetext{
${ }^{7}$ Akcję upamiętnienia mniejszości seksualnych w miejscu Zagłady mogliśmy obserwować w Polsce w 2005 roku, kiedy to grupa homoseksualistów - uczestników „Dni kultury dla tolerancji” - złożyła kwiaty pod ścianą śmierci w byłym obozie Auschwitz. Co interesujące, symbolem, który im towarzyszył podczas uroczystości była jednak tęczowa flaga, nie zaś różowy trójkąt.
} 
z latami 70. I 80. XX wieku i walką o równouprawnienie. W latach 70. odwrócony różowy trójkąt stał się symbolem ruchu wyzwolenia gejów zarówno w Europie, jak i w Stanach Zjednoczonych Ameryki Północnej (Stein 1998: 523). Pierwszy ze wspomnianych kontekstów dotyczy ponownego przyjęcia przez homoseksualistów mężczyzn różowego trójkąta jako symbolu ich oznaczającego. Wówczas nastąpiła zmiana w rozumieniu i postrzeganiu trójkąta i nadanie mu nowej wartości - miał przypominać czasy wojenne i ówczesne konsekwencje prześladowań homoseksualistów (komemoracja), ale przede wszystkim miał symbolizować walkę o równouprawnienie i szacunek. Nie zmieniała się natomiast grupa oznaczana tym symbolem, nadal byli to homoseksualni mężczyźni. Wraz z przejęciem odwróconego różowego trójkąta przez środowiska lesbijskie następuje kolejna zmiana kontekstu dla tego symbolu. Tym razem oznacza on walkę o równouprawnienie (odnosi się zatem do kontekstu opisanego wyżej w tym akapicie), ale za pomocą niego walczy już grupa niezwiązana z odwróconym różowym trójkątem w sposób bezpośredni. Jak zaznaczyliśmy w tekście, lesbijki oznaczane były w obozach koncentracyjnych czarnym, a nie różowym trójkątem, zatem przejęcie przez nie tego symbolu od społeczności gejów sygnalizuje w tym wypadku, że zmienia się grupa początkowo nim oznaczana, lecz mimo wszystko pozostaje ona związana z grupą pierwotną poprzez określoną tożsamość seksualną. Następny kontekst, w którym pojawia się odwrócony różowy trójkąt, to komemoracja. Odnosi się on zarówno do grup gejowskich, jak i lesbijskich. Obie grupy traktują ten symbol jako upamiętniający tych, którzy zginęli w obozach z powodu swojej tożsamości seksualnej. Traktowanie odwróconego różowego trójkąta jako znaku pamięci uwidacznia się poprzez umieszczanie go na pomnikach i w innych miejscach pamięci, które mają symbolizować i czcić pamięć homoseksualnych ofiar II wojny światowej.

Ostatnim kontekstem, który wyróżniliśmy, jest ten związany z pop-kulturą (omówiony w dalszej części tekstu). W tym wypadku odwrócony różowy trójkąt nie odnosi się już do swego oryginalnego znaczenia związanego z Holocaustem i napiętnowaniem homoseksualnych mężczyzn, pozbawiony jest on także znaczenia nadanego mu w latach 70. I 80. XX wieku - komemoracji i równouprawnienia. Dodatkowo, rozpowszechnienie tego symbolu w masowej kulturze konsumpcyjnej sprawiło, że przestał on odnosić się do grupy związanej z homoseksualną tożsamością seksualną. W kontekście pop-kulturowym odwrócony różowy trójkąt traci także swoje pierwotne znaczenie i może być noszony przez każdego, bez względu na tożsamość seksualną i wyznawane podglądy.

\section{Kradzież symboliczna - ujęcie modelowe}

Przedstawiając koncepcję kradzieży symbolicznej w szczególny sposób, chcielibyśmy zwrócić uwagę na zmiany dokonujące się w konotacji oraz denotacji symbolu odwróconego różowego trójkąta w ramach procesu rekontekstualizacji oraz reapropriacji. Poprzez konotację rozumiemy "dodatkowe, niedefinicyjne treści kojarzone z wyrazem przez użytkowników danego języka" (Słownik Języka Polskiego PWN). Denotatem zaś określamy "osobę lub przedmiot będący odniesieniem przynależnej mu nazwy" (Stownik Języka Polskiego PWN). Zjawisko rekontekstualizacji w przyjętym w ramach tego tekstu rozumieniu odnosi się do zmiany kontekstu postrzegania danego znaku, prowadzącej do jego nowego odczytania (Bernstein 1973: 30-33). Reapropriacja oznacza natomiast proces, w wyniku którego określenia pejoratywne stają się akceptowane społecznie ze względu na przejęcie ich przez grupy opresjonowane (Croom 2011). Powyższe definicje w odwołaniu do problematyki podejmowanej w ramach tej pracy pozwalają na skategoryzowanie kontekstów, w których wystę- 
puje różowy trójkąt w następujący sposób: zjawisko rekontekstualizacji dotyczy dwóch z opisanych fenomenów - praktyki upamiętniania za pomocą różowego trójkąta oraz jego wejścia w obszar kultury pop. Proces reapropriacji związany jest natomiast z działaniami ruchów emancypacyjnych lat 70. XX wieku, w wyniku których dotychczasowy symbol hańby, poprzez przejęcie go przez grupy opresjonowane, zyskał status symbolu akceptowanego społecznie.

Proponowana w ramach niniejszego artykułu koncepcja kradzieży symbolicznej dotyczy zmian zarówno w konotacji, jak i w denotacji symbolu różowego trójkąta w stosunku do jego pierwotnego znaczenia nadanego podczas II wojny światowej. Zmianę wartości wspomnianego symbolu zauważamy w dwóch przypadkach: w sytuacji komemoracji, w której symbol różowego trójkąta nadal oznacza homoseksualnych mężczyzn, lecz jego postrzeganie staje się pozytywne (pamięć o zmarłych jako coś dobrego) oraz w odniesieniu do praktyk emancypacyjnych, w wyniku których różowy trójkąt nadal jest używany przez homoseksualistów, jednak w procesie reapropriacji przestaje on być stygmatem. Zmiana denotatu dotyczy natomiast zjawiska przejęcia tego symbolu przez grupy lesbijskie, jak i transgenderowe - zarówno na poziomie upamiętniania (w sytuacji, gdy pomniki, w których wykorzystano motyw różowego trójkąta, odnoszą się do całej społeczności LGBT) oraz w kontekście emancypacyjnym (tu również różowy trójkąt jest wykorzystywany przez różne grupy), jak i w ramach kultury pop, gdzie przestaje być on związany z jakąkolwiek mniejszością seksualną, tracąc jednocześnie swoje odwołanie do Holocaustu. Proces kradzieży symbolicznej w ramach tego tekstu rozumiany jest zatem dwupoziomowo. Dotyczy on z jednej strony zawłaszczania wartości symbolu w ramach tej samej grupy - dla jednych homoseksualnych mężczyzn (byłych więźniów) różowy trójkąt jest znakiem hańby, dla innych zaś odnosi się do poczucia godności i dumy. Z drugiej zaś strony realizuje się poprzez zmianę odniesienia (denotatu) różowego trójkąta nie tylko w obrębie różnych mniejszości seksualnych (lesbijki oraz grupy transgendrowe), ale również poprzez bycie symbolem wykorzystywanym marketingowo w ramach kultury popularnej.

Wspomniane wieloaspektowe użytkowanie symbolu różowego trójkąta w obecnej rzeczywistości społeczno-kulturowej prowadzi do wielu pytań oraz dylematów. W niniejszym artykule pragniemy dokonać krytycznej refleksji zarówno nad, wydawać by się mogło, wykluczającą się postawą poszanowania pomięci o homoseksualnych ofiarach nazizmu, z jednoczesnym wykorzystywaniem symboliki obozowej w ramach ruchów emancypacyjnych, jak i marketingowym użyciem wspomnianego symbolu - sytuacją, gdy na specjalnych stronach internetowych można kupić: t-shirty, czapki basebolówki, kubki do kawy, emblematy do przypięcia na ubranie, naklejki na zderzak, paski, torebki, pokrowce na iphone'a z motywem różowego trójkąta.

\section{Reapropriacja i dalsza stygmatyzacja?}

Jak wykazaliśmy, odwrócony różowy trójkąt jako symbol oznaczający stygmatyzację i odrzucenie grup mężczyzn homoseksualistów podczas II wojny światowej, dziś - poprzez wykorzystanie go w ramach ruchów emancypacyjnych mniejszości seksualnych - zyskuje nowe życie znaczeniowe, które, choć nadal związane jest ze stygmatyzacją/piętnowaniem, nadaje temu procesowi zupełnie nowy charakter (tym razem pozytywny). Można tutaj zatem dostrzec, iż symbol narzucony na pewną grupę jako forma napiętnowania został przez tę grupę przejęty, a jego konotacja w drodze historycznych wydarzeń i renegocjacji uległa całkowitej zmianie, z negatywnej w pozytywną. Zjawi- 
sko przejęcia samego symbolu od grupy stygmatyzującej przez grupę stygmatyzowaną oraz zmiany jego wartości nazywamy tutaj reapropriacja. Termin ten rozumiemy za A. D. Galinskym, K. Hugenbergiem, C. Groomem i G. Bodenhausenem, którzy reapropriację określają jako „wzięcie w posiadanie przez jednych tego, co było w posiadaniu innych", i używają tego terminu w sytuacji, w której „stygmatyzowane grupy przewartościowują zewnętrznie narzucane negatywne określenie poprzez samoświadome odniesienie siebie do tego określenia. Zamiast pasywnie akceptować konotowane negatywne znaczenie danego określenia, mówiący odrzuca krzywdzące znaczenia i poprzez reapropriację nasyca określenie pozytywnymi konotacjami" (Galinsky 2003: 222). Zatem owo przejęcie symbolu odwróconego różowego trójkąta i jego przewartościowanie przez grupę stygmatyzowaną można nazwać reapriopriacją. Dodatkowo reapropriacja związana jest z "odzyskiwaniem lub przeobrażeniem krzywdzącej mowy przez jej adresatów", o czym pisze Judith Butler w kontekście performatywności aktów mowy. Według wspomnianej autorki dzięki „rytualnemu łańcuchowi resygnifikacji" możliwe jest "»odwrócenie« mowy w innej postaci przeciw temu, kto jej użył, że słowa można cytować na przekór ich pierwotnym intencjom iskutecznie odwracać ich skutki" (Butler 2010: 23). Taka siła słów do przekształcania swych znaczeń wynika z tego, że stanowią one echo swych przeszłych znaczeń. Owe słowa będące zawsze w związku z przeszłością mogą mimo wszystko zostać użyte w nowych sytuacjach społecznych, kontkestach, zatem zmienia się konwencja, w której „działają" (Butler 2010: 63). Z jednej strony istnieją w związku z przeszłym kontekstem, a z drugiej odrywają się od niego i go reformułują. Jednakże samo przekształcenie wartościowania wpisanego w symbol i jego siła zależą w dużej mierze od "luki" między źródłowym i kolejnymi kontekstami, w których dane symbole są używane, dlatego skutki przekształcenia muszą zawsze wykraczać poza pierwotny zamiar nadawcy (Butler 2010: 24). Zatem odwrócony różowy trójkąt poprzez rekontekstualizację zyskuje nowe znaczenie lub wartościowanie. Używanie go przez współczesne osoby homoseksualne czy transgenderowe do sygnalizowania emancypacji stanowi z jednej strony oderwanie od pierwotnego kontekstu używania, ale z drugiej strony zachowany jest z nim związek poprzez oznaczanie grup marginalizowanych ze względu na swoją seksualność czy odtwarzaną płeć społeczno-kulturową. Pozostaje jednak pytanie, czy proces reapropriacji nie stanowi mimo wszystko dalszej stygmatyzacji marginalizowanej grupy poprzez odwoływanie się do nazistowskiego symbolu? Czy przekucie symbolu negatywnego w pozytywny poprzez jego rekontekstualizację i resygnifikację wystarczy, aby przestał on być noszonym na piersi piętnem?

Odnosząc się do zjawiska stygmatyzacji/piętnowania, należy na początku zastanowić się, czym ono jest. Erving Goffman, zaczynając swoją pracę na temat piętna, nawiązuje do jego znaczenia pochodzącego ze starożytnej Grecji. W kulturze tej osoby niemoralne, pozostające na marginesie społecznym oznaczane były "piętnem” - znakami wycinanymi lub wypalanymi na skórze - w celu ob.wieszczenia statusu i przewinień jednostki (Goffman 2005: 31). Dziś - jak zauważa Goffman - termin ten stosuje się częściej do opisu samej hańby, a nie atrybutów, które mają na nią wskazywać (Goffman 2005: 31). Proces społecznej stygmatyzacji/piętnowania określany jest ogólnie jako naznaczenie jednostki czy grupy społecznej pewną cechą o charakterze negatywnym. Przy czym owa cecha wywołuje na tyle silne pejoratywne skojarzenia, że przesądza ona o tym, w jaki sposób określona jednostka czy grupa społeczna jest postrzegana przez innych. Proces ten jest silnie związany z redukcjonistycznym definiowaniem jednostek i grup społecznych i dewaluowaniem ich do negatywnej, wyróżniającej cechy (Kudlińska 2011). „Osoby stygmatyzowane to takie, które posiadają społeczny atrybut głęboko je dyskredytujący i które są postrzegane jako niepełnowartościowe 
z tego właśnie powodu" (Goffman za Czykwin, Stygmat 2008: 15-16). Goffman podchodzi do piętna/stygmatu jako do znamienia, które naznacza osobę je noszącą (Dovidio 2007). Stygmat jest rezultatem negatywnej cechy, z którą kojarzona jest jednostka. Jest on na nią nakładany i wiąże się ze społecznymi oczekiwaniami wobec wyglądu czy zachowania osoby napiętnowanej. Nie jest to faktyczny opis jednostki, ale sposób, w jaki kreuje się rzeczywistość wokół niej (Czykwin, Stygmat 2008). W artykule chcielibyśmy położyć silniejszy nacisk na zaproponowane przez Goffmana znaczenie stygmatu/piętna odnoszące się do czasów starożytnej Grecji ${ }^{8}$. W takim podejściu piętno związane jest z atrybutem fizycznym wskazującym na "ułomność" społeczną jednostek. Zatem interesuje nas namacalne, widoczne wskazywanie tych, którzy mają być napiętnowani, piętno jako symbol. Odwrócony różowy trójkąt podczas II wojny światowej był symbolicznym wymiarem preferencji seksualnych homoseksualnych mężczyzn. W obozach koncentracyjnych stanowił o ich odmienności. Homoseksualność mężczyzn materializowana była poprzez symbol, który stał się piętnem wyraźnie oznaczającym złe czyny, za które skazano daną osobę. Różowy trójkąt był oznaką inności, zboczenia, a w konsekwencji często powodem śmierci. Lecz to, co niegdyś poniżało w obozie, jak i poza nim, oraz stanowiło piętno - niczym szkarłatna litera z powieści Hawthorne'a - noszone na piersi, dziś wykorzystywane jest w zupełnie innym kontekście. Symbol, który oznaczał zniewolenie i jednoznacznie określał negatywnie, aktualnie konotuje się z równouprawnieniem i uwolnieniem ze społecznych ram heteronormatywności. Mamy tutaj zatem do czynienia nie tylko ze zmianą wartości symbolu, ale także z pozornym zerwaniem z procesem stygmatyzacji. Warto zauważyć, że różowy trójkąt z powodu zatarcia swojej pierwotnej wartości i jej zmiany zyskał status symbolu, który kiedyś cechował negatywnie określoną grupę, współcześnie natomiast stał się jej oznaką w pozytywnym rozumieniu i „emblematem walki o równouprawnienie" (Remin 2012: unpaged). Homoseksualiści stygmatyzowani ze względu na swoją tożsamość seksualną i definiowani w obozach za pomocą różowego trójkąta, który stał się powodem do ich dalszego napiętnowania, dziś dalej używają tego symbolu do określania siebie i swojej postawy. Lecz tym razem różowy trójkąt poprzez proces reapropriacji zyskał znaczenie pozytywne, ma kojarzyć się z czymś dobrym, z walką o równouprawnienie. Nadal jednak pozostaje pytanie, czy do zniwelowania stygmatu wystarczy by był on nadawany nie przez oprawcę, ale by ofiary same zaczęły się nim oznaczać? Czy może takie zachowanie paradoksalnie byłoby oznaką największego tryumfu oprawcy, który sprawia, że ofiary nieprzymuszone przez nikogo zaczynają myśleć w kategoriach narzuconego im stygmatu? W naszym postrzeganiu odwrócony różowy trójkąt, mimo procesów zmiany wartości i znaczenia, którym uległ, nadal stanowi piętno dla noszących go homoseksualistów ze względu na to, że nie zerwał on ostatecznie ze swoim pierwotnym kontekstem używania. Omawiany symbol wciąż odnosi się silnie do nazistowskich obozów koncentracyjnych i pozycji więźniów homoseksualnych w nich przetrzymywanych. Obozowy kontekst używania, tak zakorzeniony w odwróconym różowym trójkącie, nie może zostać łatwo zniwelowany, gdyż źródło powstania symbolu jest ustalone i znane. W tym wypadku "luka", o której wspomina Butler (Butler 2010: 24), pomiędzy skutkami jakie wywołują słowa (w przypadku omawianym w artykule zamiast słów jest to symbol) a zamiarem z jakim zostały wypowiedziane po raz pierwszy, nie jest dostatecznie duża. Oznacza to, że symbol odwróconego różowego trójkąta nadal posiada swoje pierwotne, stygmatyzujące znaczenie. Jednakże za taką

${ }^{8}$ Niniejszy artykuł nie ma na celu metodologicznej rozprawy na temat kategorii stygmatu i piętna, dlatego kategorie te będą tutaj stosowane zamiennie. w celu rozwinięcia tematu różnicy pomiędzy piętnem a stygmatem odsyłamy do prac Elżbiety Czykwin Białoruska mniejszość narodowa jako grupa stygmatyzowana oraz Stygmat społeczny. 
próbę ostatecznego oddalenia się od źródłowego kontekstu używania i stworzenia nieprzewidywalnych przez nadawcę skutków postrzegamy pojawienie się odwróconego różowego trójkąta w kontekście pop-kultury, jako produktu masowego. Takie wykorzystywanie nazistowskiego symbolu jest możliwością złamania silnej relacji pomiędzy różowym trójkątem a homoseksualistami. Różne sposoby wykorzystywania wspomnianego symbolu w ramach kultury pop, która czyni go znakiem „dla większości”, staną się przedmiotem refleksji w ostatniej części niniejszego artykułu.

\section{Pop-trójkąt}

Symbol odwróconego różowego trójkąta pojawia się w amerykańskiej kulturze w wielu odmiennych kontekstach. Mamy z nim do czynienia nie tylko na pomnikach upamiętniających ofiary homoseksualne zamordowane podczas II wojny światowej, ale także w różnych przejawach, które dziś nazwalibyśmy pop-kulturowymi. Różowy trójkąt występuje jako element ozdobny na sprzączkach do paska, gdzie czasem inkrustowany jest błyszczącymi elementami, wyszywany jest na torebkach, naklejany na zderzaki samochodów, umieszczany na pokrowcach i naklejkach do telefonów, czy też przyczepiany jako dekoracja na czapkach baseballowych i wzór na t-shirtach. Produkty te skierowane są dla ogólnego odbiorcy. Za przykład takiej oferty mogą służyć gadżety sprzedawane na portalu spreadshirt, gdzie odnaleźć możemy bluzy, koszulki, kubki, bidony czy pokrowce na iPhona z motywem różowego trójkąta. W przypadku ubrań oprócz rozmiarów dla dorosłych istnieją również wersje dziecięce. Co ważne treści zawarte na stronie nie odnoszą się w żaden sposób do wykorzystywanej symboliki, natomiast przedstawiają informacje o dostępnych rozmiarach czy jakości użytego materiału ${ }^{9}$ Przykładem takiej oferty mogą być bluzy, koszulki, czapki, torby podręczne czy kubki zaprojektowane przez użytkownika portalu Spreadshirt używającego pseudonimu JazzyDesignz (Spreadshirt 2013). W ramach oferty kupujący może również wykonać samodzielną kompozycję, dobierając do motywu różowego trójkąta różne kolory i typy koszulek.

\section{More products}

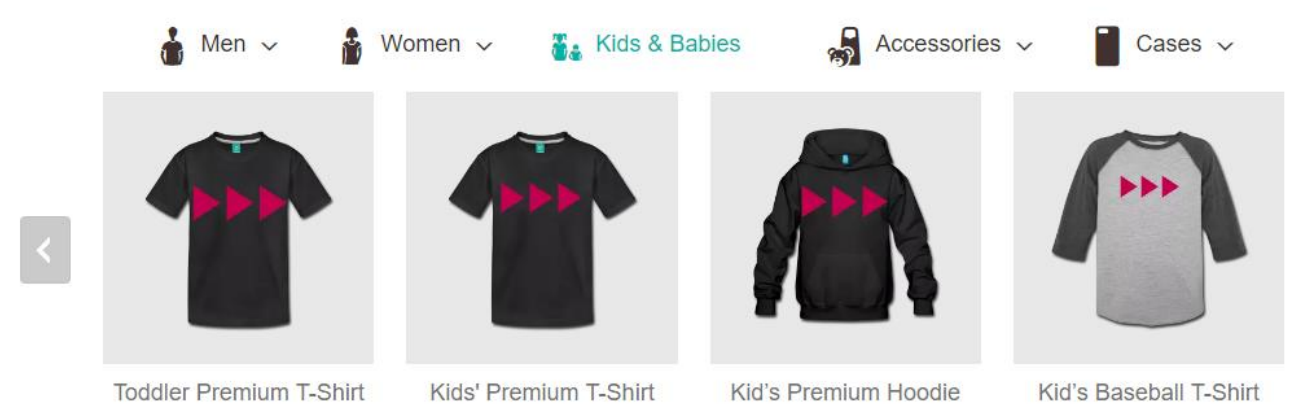

\section{Product Details}

Produktami podobnej kategorii są różowe trójkątne kolczyki, (niedostępna już) koszula męska z kieszonką w kształcie różowego firmy Milanoo, poduszki, sprzączki do paska, naszyjniki czy naklejki oparte na omawianym wzorze - są one skierowane do ogólnego odbiorcy i w znacznej mierze spełniają funkcję dekoracyjną.

9 Niestety strony internetowe prezentujące ofertę konkretnych towarów komercyjnych są efemeryczne, dlatego artykuły opisywane w tej części pracy nie są już w większości dostępne. 

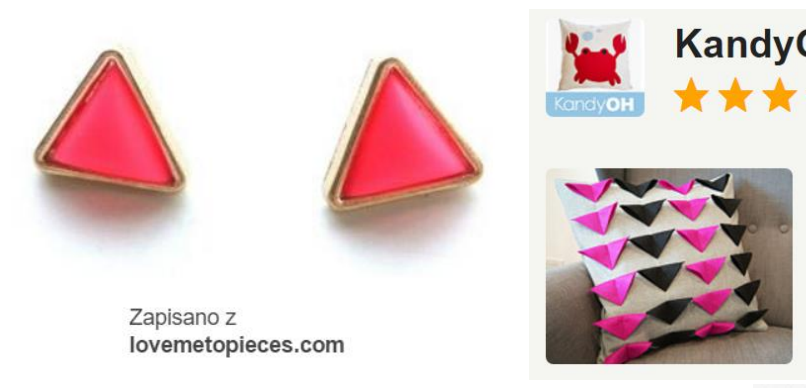

Pink Triangle Pillow Cover
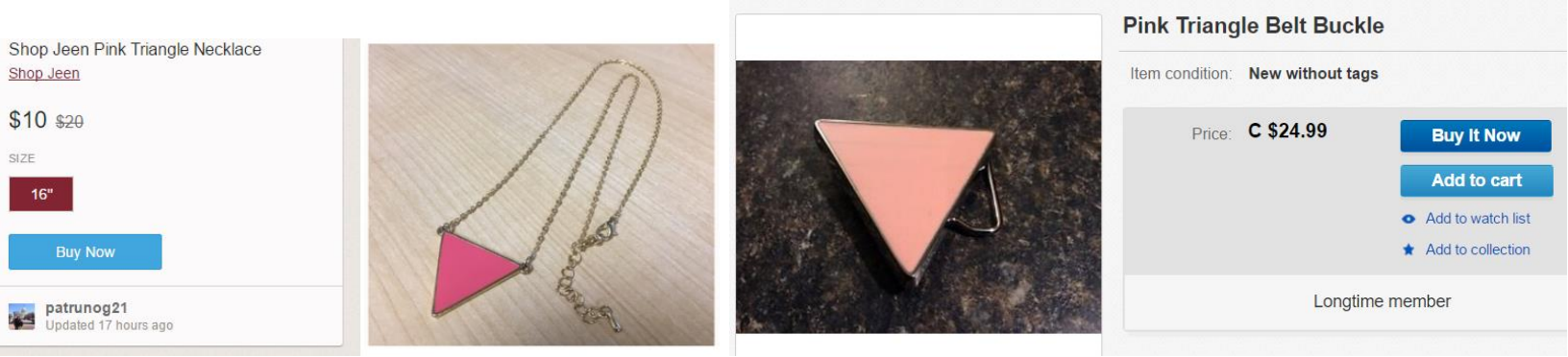

Umieszczanie odwróconego różowego trójkąta w przestrzeni mody czy też pop-kultury stanowi wyraźne przeniesienie symbolu z jego pierwotnego kontekstu. Odwrócony różowy trójkąt traci w opisanej sytuacji swoje pierwotne znaczenie związane z kategoryzowaniem więźniów w obozach koncentracyjnych, a zyskuje znaczenie oparte na pop-kulturze, modzie czy designie. Staje się symbolem, który ogólnie jest identyfikowany z wyzwoleniem i środowiskiem gejowsko-lesbijskim, lub nawet - w kontekście pop-kulturowo-modowym - traktuje się go jedynie jako pewnego rodzaju dekorację, ozdobny kotylion.

Różowy trójkąt - tak jak wspominaliśmy wcześniej - może być manifestacją przynależności do pewnej grupy lub jej popierania i wtedy powoli przestaje być kojarzony z uciemiężeniem i cierpieniem, a zaczyna być kojarzony z wolnością i wyzwoleniem. Jednak to przenoszenie znaczeń w tym przypadku nie oznacza dostatecznego zerwania z kontekstem pierwotnym oraz z zamiarami tego, kto narzucił symbol. Dlatego też, jak zaznaczyliśmy wyżej, w naszym odczuciu odwrócony różowy trójkąt kontynuuje stygmatyzację grup marginalizowanych ze względu na swoją tożsamość seksualną. Sytuacja zmienia się jednak, gdy trójkąt użytkowany jest w kontekście mody (już bez odniesień emancypacyjnych). Staje się on wtedy częścią świata ściśle związanego z przyjemnością i konsumpcją. Dochodzi także do „wyniesienia z obozu” odwróconego różowego trójkąta, jego oderwania od małej określonej grupy - homoseksualnych mężczyzn - a następnie pojawiania się w kontekście pop-kulturowym, masowym i ogólnoludzkim. Symbol już zatem nie stygmatyzuje, ale naznacza pozytywnie różne grupy ludzkie, niezależnie od ich tożsamości seksualnej. W odniesieniu do pop-kulturowego wykorzystywania różowego trójkąta warto zwrócić uwagę również na fakt przeniesienia go w przestrzeń konsumpcyjną. Staje się on elementem związanym z komercją. Symbol przeszłego cierpienia służy obecnie do zarabiania pieniędzy. Gadżety, na których znajduje się dekoracja w postaci odwróconego różowego trójkąta, stają się przedmiotem internetowych aukcji czy produktem udostępnianym w sklepach online. Współcześnie każdy może zakupić sobie koszulkę z odwróconym różowym trójkątem czy pokrowiec do telefonu komórkowego, na którym znajduje się ten symbol. Prezentowane podejście do omawianego symbolu znacznie wpływa na jego postrzeganie i rozumienie w społeczeństwie. Symbol, jakim jest różowy trójkąt, został umasowiony i sprowadzony do roli produktu. 
Wydaje się więc, że jednym ze sposobów obłaskawienia symbolu o strasznej historii może być zabieg rozszerzenia grupy jego odbiorców, ale o taką grupę, która z symbolem nie ma ani zwiążków bezpośrednich (takich jak w przypadku gejów), ani pośrednich (jak w przypadku lesbijek). Wskazywana przez nas masowość różowego trójkąta (odłączenie go od grupy homoseksualnych mężczyzn i kobiet) oraz sprowadzenie go do roli produktu konsumpcyjnego stwarzają, jak się wydaje, najbardziej diametralną możliwość przełomu dyskursywnego, umożliwiającego zerwanie z kategorią piętna w jego tradycyjnym znaczeniu. Różowy trójkąt z symbolu przeznaczonego dla ściśle okreśIonej mniejszości, którą miał piętnować, stał się nadrukiem dla większości, dla której jego przeszłe znaczenie wydaje się nie być tak istotne, a najprawdopodobniej nie jest wcale znane. Otwiera się tym samym kolejna możliwość przekształcenia wartości symbolu, ponieważ następuje zatarcie jego pierwotnego kontekstu użytkowania i oderwanie od grupy narzucającej - nazistów. Takie skutki jak poszerzenie denotacji o grupę niezwiązaną z Holocaustem (umasowienie) oraz odejście od obozowego, nazistowskiego życia odwróconego różowego trójkąta stanowi rekontekstualizację nieobarczoną stygmatyzacją, wolną od przeszłych znaczeń i grupy uciskającej. Wspomniana przez Butler "luka" wydaje się w wypadku pop-kultury i konsumpcyjnego charakteru tego symbolu wystarczająca.

\section{Zakończenie}

Wspomnianemu na początku tej pracy Prometeuszowi, chyba jako jednemu z niewielu, udało się pogodzić kradzież ze szlachetnością. Inaczej niż w mitycznym świecie bogów, w rzeczywistości ludzkiej czyn taki wydaje się być zjawiskiem wywołującym wiele dylematów. W niniejszym tekście staraliśmy się opisać oraz przeanalizować sytuację, w której to silnie utrwalony historycznie symbol zyskuje zupełnie nowe znaczenie oraz wartościowanie w procesie rekontekstualizacji oraz reapropriacji. Przedstawione w ramach tego artykułu różne konteksty występowania odwróconego różowego trójkąta wydają się być nie tylko interesującymi przypadkami konstruowania dyskursów oraz mechanizmów tworzenia znaczenia i jego zmiany, ale mają również silne konotacje natury etycznej i emocjonalnej. Pojęcie holocaustowego szaberku wprowadzone na początku niniejszego artykułu, miało za zadnie zwrócić uwagę na to, że nie tylko przedmioty fizyczne mają swoje ograniczenia, jeżeli chodzi o prawo własności, ale że prawo to może stanowić klucz do zrozumienia procesów odbywających się na poziomie symbolicznym.

Próba przyjrzenia się zjawisku rekontekstualizacji symbolu różowego trójkąta w kategoriach zmiany jego denotatu oraz konotacji miała, w naszym ujęciu, wskazać na mechanizmy umożliwiające redefiniowanie i przywłaszczanie symboli (określane przez nas wspólnym mianem kradzieży symbolicznej). Dodatkowo w odniesieniu do koncepcji Judith Butler staraliśmy się wskazać na różne poziomy oderwania symbolu różowego trójkąta w stosunku do jego pierwotnego znaczenia, jak i na wynikające z tego konsekwencje.

Zasadniczy przedmiot refleksji w niniejszym tekście stanowiła kultura północnoamerykańska. Należy zauważyć, że artykuł ten nie miał na celu holistycznego ujęcia problemu, lecz podkreślenie możliwie wielu rysujących się kontrastów w sposobach wykorzystywania symbolu różowego trójkąta. Jednocześnie badania nad omawianą problematyką w innych kulturach mogą przynieść opisy nowych sposobów wykorzystywania omawianego symbolu. 


\section{Bibliografia}

Bernstein, Basil. 1973. Class, Codes and Control. Tom 3: Towards a Theory of Educational Transmission. London: Routledge \& Kegan Paul, s. 30-33.

Butler, Judith. 2010. Walczace słowa. Tłum. A. Ostolski. Warszawa: Wydawnictwo Krytyki Politycznej.

Connelly, John. 2010. Gypsies, Homosexuals, Slavs. W: (red.) Hayes, Peter, Roth, John K. The Oxford Handbook of Holocaust Studies. Oxford: Oxford University Press, s. 274-293.

Croom, Adam M. 2011. Slurs. W: „Language Sciences" 33.3, s. 343-358.

Czarnobyl: Dar Prometeusza. http://www.eksel.user.icpnet.pl/opowiadania/4miszmasz/ czarnobyl9.php; dostęp: 03.11.2012.

Czykwin, Elżbieta. 2000. Białoruska mniejszość narodowa jako grupa stygmatyzowana. Białystok: Trans Humana.

- - -. 2008. Stygmat społeczny. Warszawa: Państwowe Wydawnictwo Naukowe.

Dovidio, John F., Major, Brenda, Crocker. Jennifer. 2007. Piętno. W: (red.) Heatherton, Todd F., Kleck, Robert E., Hebl, Michelle R., Hull, Hay G. Społeczna psychologia piętna. Warszawa: Państwowe Wydawnictwo Naukowe, s. 23-43.

Elman, Amy R. 1996. Triangles and Tribulations: The Politics of Nazi Symbols. W: „Journal of Homosexuality" 30.3, s. 1-11.

Epstein, Rob, Friedman, Jeffrey, reż. 2000. Paragraf 175.

Galinsky, Adam D., Hugenberg, Kurt, Groom, Carla, Bodenhausen, Galen. 2003. The reappropriation of stigmatizing labels: implications for social identity. W: „Research on Managing Groups and Teams" 5, s. 221-256.

Gay and Lesbian Holocaust Memorial, Green Park, Sydney. Lesbian and Gay Solidarity Melbourne. http://www.josken.net/glhmp2.htm; dostęp: 07.12.2012.

Goffman, Erving. 2005. Piętno. Rozważania o zranionej tożsamości. Tłum. A. Dzierżyńska, J. Tokarska-Bakir. Gdańsk: Gdańskie Wydawnictwo Psychologiczne.

Homocaust: The Gay Victims of the Holocaust. www.homocaust.org; dostęp: 02.03.2013.

Homoseksualiści oddali hołd ofiarom Auschwitz. 23.04.2005. www.wiadomosci.wp.pl; dostęp 6.09.2013.

Kudlińska, Iwona. 2011. Stygmatyzacja społeczna jako perspektywa teoretyczno-badawcza (na przyktadzie badań nad stygmatyzacja ludzi biednych). W: „Folia Sociologica", s. 51-72.

Levvy, Daniel, Sznaider, Natan. 2006. The Holocaust and Memory in the Global Age. Philadelphia: Temple University Press.

LGBT na świecie i w Polsce. gaymateo.pl - Polski Gay Portal. http://gaymateo.pl; dostęp: 22.11.2012.

Polski Związek Byłych Więźniów Politycznych Hitlerowskich Więzień i Obozów Koncentracyjnych. http://www.pzbwp.org; dostęp: 22.11.2012.

Próbował wywieźć drut kolczasty z Auschwitz. „Polskie Radio” 12.08.2012.

http://www.polskieradio.pl/5/3/Artykul/664515,Probowal-wywiezc-drut-kolczasty-z-Auschwitz; dostęp: 03.11.2012. 
Remin, Katarzyna. 2012. Wprowadzenie. W: (red.) Remin, Katarzyna. Różowe trójkąty. Zbrodnie nazistów na osobach homoseksualnych w kontekście edukacji antydyskryminacyjnej. Warszawa: Kampania Przeciw Homofobii, s. 10-14.

Sidorowicz, Jarosław. 2010. Szwed skazany za kradzież napisu „Arbeit Macht Frei”. "Gazeta Wyborcza: Kraków" 31.12.2010. http://wyborcza.pl/1,76842,8888082,Szwed skazany za kradziez napisu Arbeit macht frei .html; dostęp: 03.11.2012.

Stownik Języka Polskiego PWN. http://sjp.pwn.pl/slownik.

Spread Shirt. www.spreadshirt.com; dostęp: 05.09.2013.

Stein, Arlene. 1998. Whose Memory? Whose Victimhood? Contests for the Holocaust Frame in Recent Social Movement Discourse. W: „Sociological Perspective" 4, s. 519-540.

The Gay Holocaust - Memorials. http://andrejkoymasky.com/mem/holocaust/ho08.html; dostęp: 22.11.2012.

Weseli, Agnieszka. 2007. Homoseksualiści i homoseksualizm w KL Auswitz-Birkenau w świetle "oświadczeń" byłych więźniów obozu. W: „Przegląd Historyczny" 98, s. 425-435.

Zapadt wyrok w sprawie kradzieży w Auschwitz. "Polskie Radio" 17.02.2012.

http://www.polskieradio.pl; dostęp: 03.11.2012. 